\title{
$\underline{\mathbf{P}-155}$
}

\section{Acute Toxicity Study of Myrmecodia Platytyrea Aqueous Tuber Extract}

\author{
Maisarah Mohd Zin, Mizaton Hazizul Hasan*, Ibtisam Abdul Wahab, Thellie Ponto and Aishah \\ Adam \\ Faculty of Pharmacy, Universiti Teknologi MARA, 42300 Bandar Puncak Alam, Malaysia; \\ E-mail: mizaton_hazizul@puncakalam.uitm.edu.my
}

Myrmecodia platytyrea which is locally known as sarang semut is an epiphytic plant that belongs to the family of Rubiacea. In Papua Island, decoction of $M$. platytyrea tuber is used as a remedy for treatment of minor ailments to severe diseases. To date, there is no documented evidence regarding the safety of $M$. platytyrea aqueous tuber extract. Thus, this research aims to investigate the toxicity of the aqueous tuber extract of $M$. platytytrea tuber by determining its effects after acute oral administration in male and female albino mice. A single oral administration was performed at $2000 \mathrm{mg} / \mathrm{kg}$ body weight in both male and female mice and observed for 24 hours for mortality. The results showed no signs of toxicity such as general behavioural changes and changes on gross appearance. No mortality was also reported. The extract also did not exhibit any significant $(P>0.05)$ effects on body weight, absolute organs weights, hematological and blood chemistry levels in treated mice as compared to the control group. $M$. platytyrea aqueous tuber extract showed no toxicity in male and female albino mice thus, safe for consumption.

Keywords: Myrmecodia platytyrea, Acute toxicity, Mice, Mortality, Blood analysis. 